\title{
Paleomagnetism of the Avalonian Finn Hill sequence of Eastern Newfoundland, Canada
}

\author{
M.K.-Seguin, Faculty of Science and Engineering \\ Universite Laval, Quebec, Canada G1K $7 P 4$
}

\begin{abstract}
As part of a major study of the Avalon zone in eastern Newfoundland, the paleomagnetism of the Finn Hill ignimbrite sequence located in the Colliers-Harbour Main area is described. Detailed alternating field and thermal experiments performed on this Hadrynian ash-flow tuff sequence indicate that it is characterized by two significantly different mean directions of magnetization: 1) $A\left(S=128, I=+25, \alpha 95=7.1^{\circ}\right.$, $K=171, N=4$ sites) in-situ and $\left(D=225, D+59, \alpha_{95}=13^{\circ}, K=48\right)$ after tilt correction, 2) $B(D=69, I=+52, N=$ 2 sites) in-situ and $(D=303, I=+40)$ after tilt correction.

The A component is believed to be secondary and the paleopole corresponding to the in-situ direction of magnetization is $14^{\circ} \mathrm{S}, 1^{\circ} \mathrm{W}$. The $\mathrm{B}$ tilt corrected component $(\mathrm{D}=303, \mathrm{I}=+40)$ is interpreted as a pre- or syn-folding direction of magnetization corresponding with the time of formation of the ignimbrite sequence or slightly later; its corresponding paleopole position is $39^{\circ} \mathrm{S}, 29^{\circ} \mathrm{E}$. It is worth noting that the paleopole $\left(14^{\circ} \mathrm{S}, 1^{\circ} \mathrm{W}\right)$ of the secondary component found in the present study is not significantly different from the paleopole $\left(5^{\circ} \mathrm{S}, 8^{\circ} \mathrm{W}\right)$ obtained in the Cloud Mountain basalt overlying Grenville basement of northwestern Newfoundland, the age of which is close to latest Precambrian $(\approx 620 \mathrm{Ma})$. this suggests that in late Precambrian time, the eastern and western Newfoundland blocks were not very distant from each other or else they were far apart but at the same paleolatitude. The secondary component is interpreted as representing the magnetic imprint of the Avalonian (Cadomian) orogenic event. This last interpretation is reasonable since nearby Cambrian units (to the west) are located unconformably above the Precambrian units and are almost flat lying. Consequently, the chances of this secondary component being of Acadian age are relatively small. The new data set of this reasearch fills a definite gap in the paleomagnetic record of the Avalon zone.
\end{abstract}

La description du paleomagnétisme de la séquence d'ignimbrite de Finn Hill, situee dans la région de Colliers - Harbour Main, s'insère dans le cadre d'une étude d'envergure de la zone Avalon de l'est de Terre-Neuve. Cette séquence hadrynienne de tuf volcanique a été soumise à des expériences poussées de champ alternatif et d'anlyse thermique. Les résultats indiquent que la séquence est caractérisée par deux sens moyens de l'aimantation qui diffèrent de façon significative: l) $A\left(S=128, I=+25, \alpha_{95}=7.1^{\circ}, K=171, N=4\right.$ sites) in-situ et $\left(D=225, D+59, \alpha_{95}=13^{\circ}, K=48\right)$ après correction de l'inclinaison, 2) $B(D=69, I=+52, N=2$ sites) in-situ et $(D=303, I=+40)$ apres correction de l'inclinaison.

La composante A serait secondaire et le paléopôle correspondant au sens in-situ de l'aimantation est de $14^{\circ} \mathrm{S}, 1^{\circ} \mathrm{O}$. On interprète la composante d'inclinaison $\mathrm{B}$ corrigée $(\mathrm{D}=303, \mathrm{I}=+40)$ comme le résultat d'une aimantation qui a précédé ou qui était contemporaine au plissement, et correspondant donc au temps d'emplacement de la séquence d'ignimbrite, ou survenant peu après; la position du palépôle correspondant est de $39^{\circ} \mathrm{S}, 29^{\circ} \mathrm{E}$. Il est intéressant de noter que le palépôle $\left(14^{\circ} \mathrm{S}, 1^{\circ} \mathrm{O}\right)$ de la composante secondaire, relevé dans la présente étude, ne diffère pas de façon significative du palépôle $\left(5^{\circ} \mathrm{S}, 8^{\circ} \mathrm{O}\right)$ obtenu à partir du basalte de Cloud Mountain qui recouvre le socle grenvillien dans le nord-ouest de Terre-Neuve et dont l'âge est proche du Précambrien tardif $(620 \mathrm{Ma})$. Ceci suggère que tard durant le Précambrien, les blocs est et ouest de Terre-Neuve n'étaient pas très distants, ou bien qu'ils étaient très éloignés l'un de l'autre mais situés à la même paléolatitude. On interprète la composante secondaire comme une empreinte magnétique représentant l'orogenèse avalonienne (Cadomien). Cette dernière interprétation est raisonnable puisque les unités cambriennes voisines (à l'ouest) reposent subhorizontalement et en discordance sur les unités précambriennes. Conséquemment, il est peu probable que cette composante secondaire soit d'âge Acadien. Ces nouvelles données comblent une lacune importante dans l'histoire paleomagnétique de la zone Avalon.

[Traduit par le journal]

\section{INTRODUCTION}

The eastern segment of the Appalachian orogen in Newfoundland is underlain by Late Precambrian (Hadrynian) rocks. The Precambrian orogeny which affected these rocks was named "Avalonian" after the Avalon Peninsula of eastern Newfoundland (Lilly 1966, Poole 1967) where they are best exposed. Systematic mapping programs of the Avalon Zone were first undertaken by Hutchinson (1953) and McCartney (1956, 1957). Detailed studies in the eastern Ava-

\section{MARITIME SEDIMENTS AND ATLANTIC GEOLOGY} 21, 55-68 (1985) lon Peninsula (study area) have been carried out by Papezik (1969, 1970, 1972), Nixon (1975), Nixon and Papezik (1979) and King (1979). The Precambrian stratigraphy was elucidated subsequently by many workers including King et al. (1974), King (1979), Strong (1979) and Williams and King (1979).

The Avalon Peninsula was affected by two principal orogenies, a Late Precambrian "Avalon orogeny" and the "Acadian" orogeny of Middle to Late Devonian age (Williams et al. 1972, Dallmeyer et al. 1983). Different tectonic models have been 
proposed for the origin of the Avalon mini-continent: 1) volcanic islands (Hughes and Bruckner 1972) and ensialic island arc (Rast et al. 1976); 2) subduction and Basin and Range - type rifting (Papezik 1970, Schenk 1971, Strong et al. 1974, Strong 1979); 3) continental (Basin and Range) extension and rifting (Rankin 1976). In recent models the Avalon zone is regarded as terrane exotic to North America and a suspect terrane (Williams and Hatcher 1982, 1983). Precambrian rocks similar to the ones in the Avalon Zone of Newfoundland occur along the length of the Appalachian orogen in Nova Scotia, New Brunswick, eastern Massachusetts, southeastern United States (Carolina Slate, Raleigh, Eastern Slate, Kiokee Belts) (Schenk 1971, Rankin 1976, Williams 1979), and on the eastern side of the Atlantic, i.e. Wales, Brittany, the Iberian Peninsula, Czechoslovakia and Turkey as well as in northeast Africa (Choubert 1935, Schenk 1971, Cogné 1972, Rast et al. 1976, Strong 1979, Williams 1979, O'Brien et al. 1983).

\section{GEOLOGICAL SETTING}

In the Colliers-Harbour Main study area (Fig. 1), the Late Precambrian rocks of the Avalon Zone are subdivided into three groups: 1) Harbour Main Group volcanic rocks; 2) Conception Group composed of volcaniclastics considered to be derived from the Harbour Main Group; 3) an upper sedimentary succession consisting of the St. John's Group and Signal Hill Group. North of Colliers (Fig. 1), these groups are overlain locally by Lower Cambrian shales. The Harbour Main Group is composed of marine and terrestrial volcanics. Generally, the lithological groups are weakly metamorphosed and contain prehnite-pumpellyite sub-facies mineral assemblages. The Harbour Main Group is intruded to the south by the Holyrood granite. Contact metamorphic effects with some rock units of the Harbour Main Group near and within the Holyrood plutonic rocks have been recognized, but not within the ignimbrites. Small basic dikes (diabasic gabbro and diabase) cut the Harbour Main Group.

The Finn Hill ignimbrite sequence, part of the Harbour Main Group, has a strike length of $6.4 \mathrm{~km}$ (strike $-10^{\circ}$, dip $-80^{\circ} \mathrm{W}$ ) and comprises 20 recognizable lithological units, including 12 ash-flow units intercalated with epiclastic breccia and finergrained sediments (Papezik 1969, 1972 see (Fig. 2). The largest volume of ignimbrites consists of reddish-gray to dark red crystal tuffs and vitric tuffs with variable amounts of albite, quartz, and biotite crystals and lithic fragments in a recrystallized vitroclastic matrix cemented with hematite dust. Pyroclastic units include crystal tuffs with pumice fragments. The mineralogy of the crystal fraction is characterized by small amounts of augite and sparse chloritic pseudomorphs after olivine. Basalts and porphyrite fragments are inclusions in the ash-flow sheets and pyroclastic units. In summary, the ignimbrites include an important proportion of felsic pyroclastics (including ash-flow tuffs) and intercalated terrestrial sediments and a smaller fraction of basaltic flows; the environment is typically subaerial. The primary textures of these rocks are well preserved; a lack of penetrative deformation is also evident.

\section{AGE}

Anderson (1972) suggested an age range of about 800-600 Ma for the Conception Group while Stukas (1977) provided ${ }^{40} \mathrm{Ar} /$

${ }^{39} \mathrm{Ar}$ ages for Harbour Main Group volcanics as old as 1500 Ma (see also Stukas and Reynolds 1976); this last age is anomalous. Rast et al. (1976) and Strong (1979) correlated the Love Cove Group volcanics from the Burin Peninsula, southeastern Newfoundland with the Harbour Main Group. Rast et al. (1976) correlated the largest part of the Coldbrook Group volcanic rocks with the Love Cove and Harbour Main Groups and they assigned an age ranging from 750 to $650 \mathrm{Ma}$ to the Coldbrook Group. Finally, on the basis of the observed field relationships, McCartney (1967) considers the Holyrood pluton as a single intrusion post-dating the Harbour Main Group volcanics; the granitic portion of the pluton has been dated at $575 \pm 11$ $\mathrm{Ma}$ using the $\mathrm{Rb}-\mathrm{Sr}$ method $(609 \pm 11 \mathrm{Ma}$ using $\left.{ }^{87} \mathrm{Rb}=1.39 \times 10^{-1} \mathrm{yr}\right)$. Krogh et al. (1983) obtained an age of $621 \pm 2 \mathrm{Ma}$.

In summary, the Harbour Main Group volcanics are older than $620 \mathrm{Ma}$ and prob- 
ably younger than $800 \mathrm{Ma}$; an inter- in red tuffaceous rocks and the others mediate age of about $750 \mathrm{Ma}$ is plausible (sites 8,9 as well as 4 out of 5 samples and on this basis King (1970) suggested from site 14) in grayish-green to dark green that the Harbour Main Group may be tuffaceous rock types (Fig. 2). The oriented related in time to the Vendian of northern hand samples were cored in the laboratory. Eurasia.

Field and laboratory sampling procedures

Some 35 oriented samples (99 specimens) were collected on seven different sites; the orientation was taken with a Brunton compass. The number of samples per site was fixed at 5 and the number of specimens per sample varied between 2 and 4 . The majority of the samples were collected The sample localities were chosen with reference to detailed geological maps (Nixon and Papezik 1979). Great care was taken to avoid excessively altered rock units.

\section{EQUIPMENT USED}

The direction and intensity of remanent magnetization were measured with a digital spinner magnetometer (model DSM-1) manufactured by Schonstedt Inst. Co. coupled

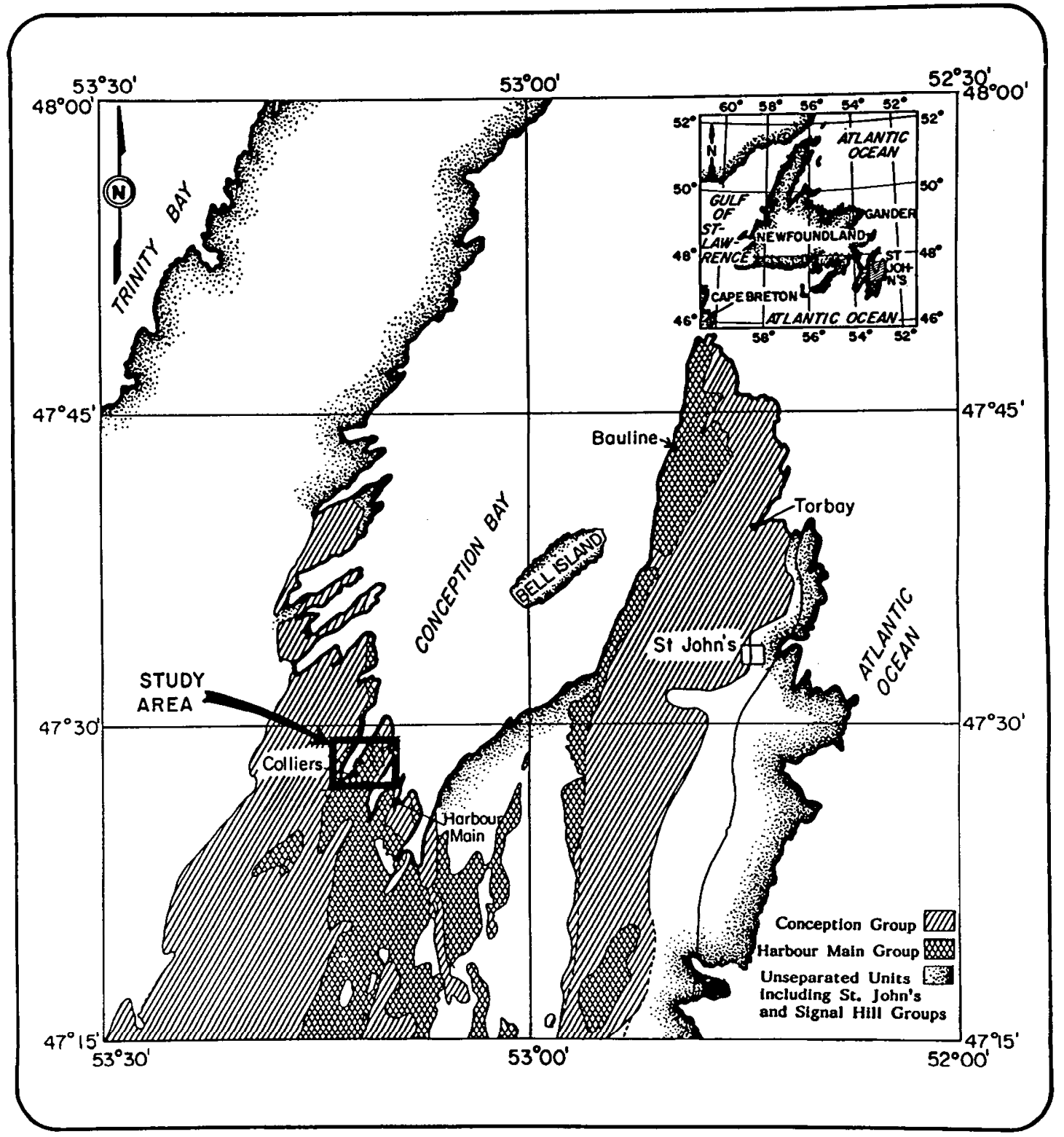

Fig. 1 - General geology of the northern Avalon sector of Newfoundland and location of the study area. 


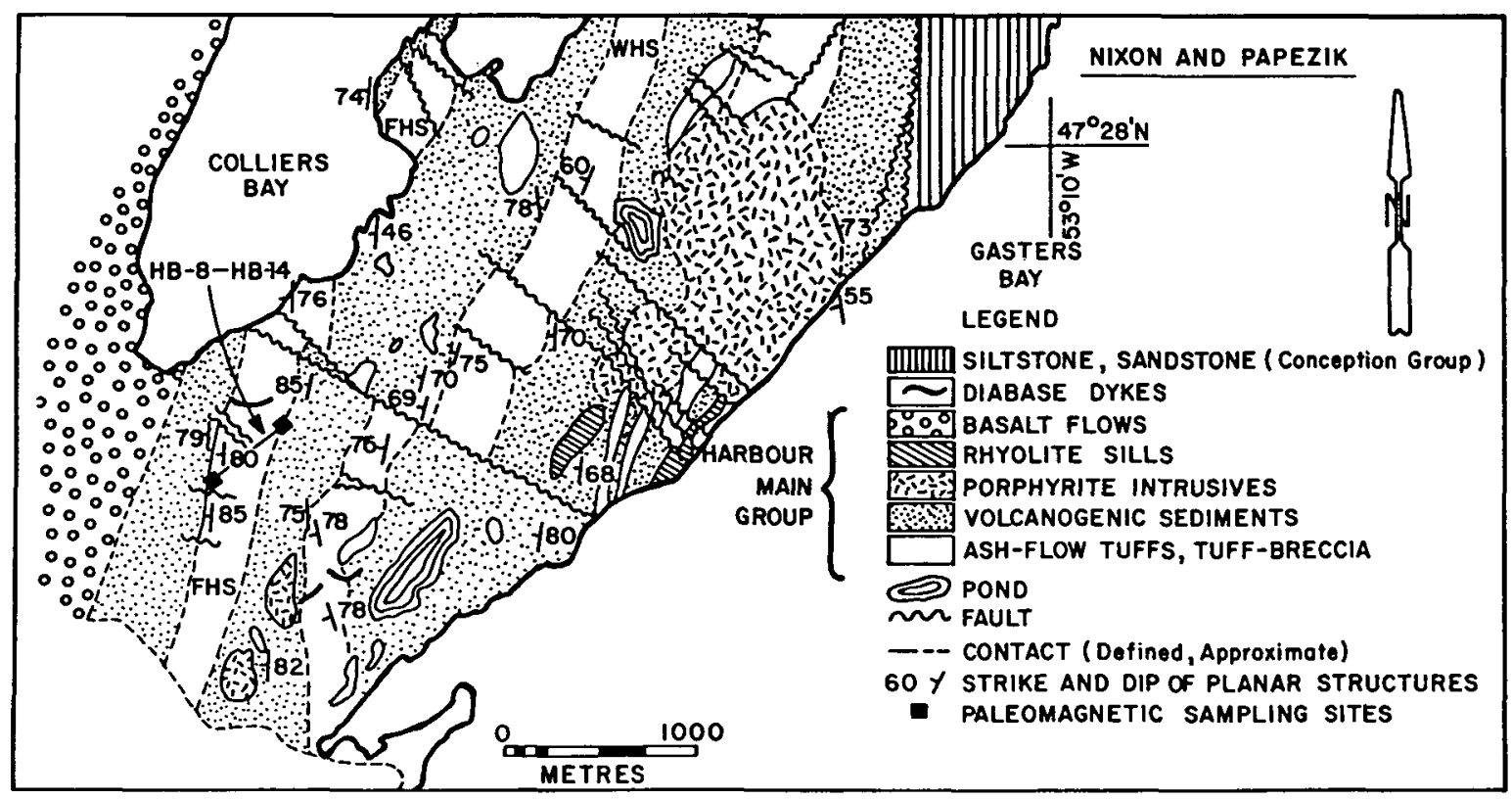

Fig. 2 - Detailed geology of the study area (after Nixon and Papezik 1979) and distribution of the paleomagnetic sampling sites (HB 8 to HB 14). FHS = Finn Hill sequence and WHS $=$ Weaver's Hill sequence. The sites are distributed over some 700 meters, that is its entire thickness.

to PDP-l and APPLE Il minicomputers in tandem. The volume susceptibility was measured at room temperature in the Earth's field $(H=0.05$ millitesla $(m T))$, using a Cenco MS-3B susceptibility bridge. Alternating field (AF) demagnetization was carried out using a demagnetizer built at Université Laval having a maximum peak-topeak field of $90 \mathrm{mT}$, the performance of which was largely improved by adding three large concentric mu-metal cylinders around the solenoid (Seguin 1975); a three-axis tumbler was used with this unit. Other AF demagnetizations were done using a Schonstedt GSD-1 apparatus (100 $\mathrm{mT}$ peak-to-peak field). Stepwise thermal demagnetization tests were carried out using a Schonstedt demagnetizer (TSD-1). The amount of residual ambient field is 5 to $10 \mathrm{nT}$ in the $\mathrm{AF}$ and thermal demagnetizers respectively.

\section{REMANENT ORIENTATIONS AND INTENSITIES}

Sample-mean natural remanent magnetization (NRM) directions (Fig. 3), although characterized by relatively pronounced smearing of positively inclined steep remanence, have a pronounced deviation away from the present Earth's field (PEF) (D= $\left.335^{\circ}, \mathrm{I}=76^{\circ}\right)$ at the site localities. Most of the NRM directions are located in the southeastern quadrant in a subvertical plane oriented at $130^{\circ} \pm 20^{\circ}$. The extreme NRM directions are roughly aligned with the PEF and the A component respectively. Component $\mathrm{A}$ is obtained by both $\mathrm{AF}$ and thermal demagnetizations and will be described in the two next sections. This observation indicates that different samples contain varying proportions of the $A$ component and the PEF-directed component. The site-mean direction of the remanence is $D_{0}=128^{\circ}$, $I_{0}=67^{\circ}, N=7, \alpha 95=25.7^{\circ}, K=6.5$ for the Finn Hill sequence (FHS) in-situ and $D_{1}=267^{\circ}$, $\mathrm{I}_{1}=29^{\circ}, \alpha 95=24.9^{\circ}, \mathrm{K}=6.9$ when tilted back to the horizontal. These directions indicate that the FHS rocks do carry some ancient remanence especially since the directions of the remanence for the four samples that lie close to the PEF were found to move away from these initial directions during subsequent $\mathrm{AF}$ or thermal demagnetizations. The intensities of NRM $\left(\mathrm{J}_{n}\right)$ vary from $2 \times 10^{-3}$ to $5 \times 10^{-1} \mathrm{Am}^{-1}$ with Koenigsberger's ratio $\left(Q_{n}=J_{n} / K H\right)$ between 0.2 and 20 but with predominant ratios between 0.4 and 5 (Fig. 3).

\section{a) AF demagnetization}

For the pilot AF study, at least 10 but usually 12 specimens for each of the seven sites of FHS were demagnetized in 13 steps up to $100 \mathrm{mT}$ wherever the intensities were large enough to warrant it, and vector dia- 
grams. (Zijderveld 1967) were used in the subsequent analysis. For $50 \%$ of the specimens the intensities of magnetization fall off to less than $10 \%$ of the original NRM intensity in the interval: $30-90 \mathrm{mT}$ (average: $60 \mathrm{mT}$ ). In $85 \%$, the median destructive field $\left(\mathrm{H}_{1}\right)$ is found to be below $100 \mathrm{mT}$ in the range. $10-70 \mathrm{mT}$ (average $=25 \mathrm{mT}$ ). Samples from sites $\mathrm{HBl} 2$ and $\mathrm{HBl3}$ have a median destructive field larger than 100 $\mathrm{mT}$. In almost $40 \%$ of the AF demagnetized samples, the measurements indicated acquisition of spurious magnetizations at higher demagnetizing fields $(70-100 \mathrm{mT})$. This phenomenon is caused by the instability of magnetite at higher field and so thermal treatment was more efficient than AF demagnetization in the majority of the samples. Generally, vector trajectories are linear until stable end-points are reached at higher fields and a univectorial component (SE, shallow positive) is obtained once the low coercivity (soft) component is removed in the 5-20 $\mathrm{mT}$ range (average: 10 $\mathrm{mT})$. This soft component was observed in about $35 \%$ of the samples; upon its removal, the declination remains unchanged but the inclination (intermediate or steep positive) becomes shallow positive. Specimen HBl3-3.B (Fig. 4) is a representative example of in-situ component A (SE, shallow positive) while specimen HB 8-1.B (Fig. 4) is a typical example of a PEF component $\left(\mathrm{H}_{\frac{1}{2}}=5-10 \mathrm{mT}\right)$ superimposed on in-situ component $B$ (East, intermediate positive) in the $70-100 \mathrm{mT}$ range. $\mathrm{AF}$ demagnetization tests and identification of the opaques with the aid of a reflecting microscope have shown that the magnetic memory carrier in samples of sites HB 10 , 11,12 and 13 is mainly hematite. On sites HB 12 and 13 in particular, the relative intensity of NRM is still at the $80 \%$ level after demagnetization at $100 \mathrm{mT}$. On sites HB 8 and HB 9, the memory carrier is principally magnetite with an average median destructive field of $15 \mathrm{mT}$. In the case of site HB 14, the memory is located principally in the hematite for one sample while for the other four samples it is mainly in magnetite. Consequently, AF demagnetization was concentrated in samples of sites $\mathrm{HB} 8,9$ and 14 and to a lesser extent to sites $\mathrm{HB} 10$ and 11 .

\section{b) Thermal cleaning}

Five (5) to 10 specimens for each of the seven sites were thermally cleaned in a minimum of 13 steps up to $660^{\circ} \mathrm{C}$, and vector diagrams were used in the subsequent analysis of the results. Most commonly, the unblocking temperature $\left(T_{U B} !\right.$ is located in the $300-660^{\circ} \mathrm{C}$ range (usually $500-650^{\circ} \mathrm{C}$ ) with two main modes; one at temperatures smaller than $560^{\circ} \mathrm{C}$ and the other around $600^{\circ} \mathrm{C}$ or more. The first
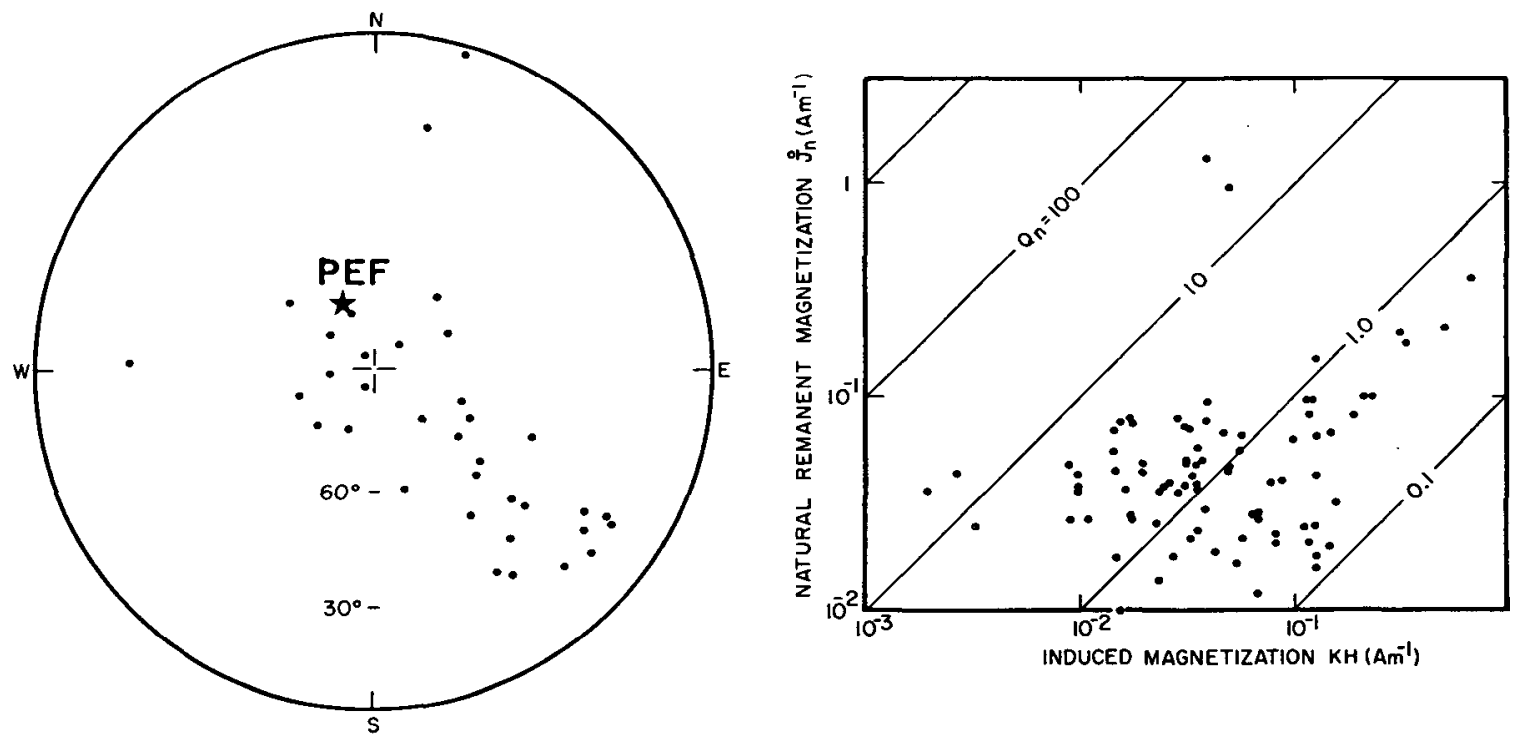

Fig. 3 - Individual sample NRM directions plotted on Wulff net for sites HB8 to HBl4 (left). The solid circles represent projections on lower hemisphere. The star represents the present Earth's field (PEF) at the sampling locality. Plots of intensity of NRM ( $\mathrm{Jn}$ in $\mathrm{Am}^{-1}$ ) against the induced magnetization ( $\mathrm{KH}$ in $\mathrm{AM}^{-1}$ ) with resulting slope lines indicating the values of Koenigsberger ratio, $\mathrm{Q}_{\eta}$ (right), for all individual specimens. 

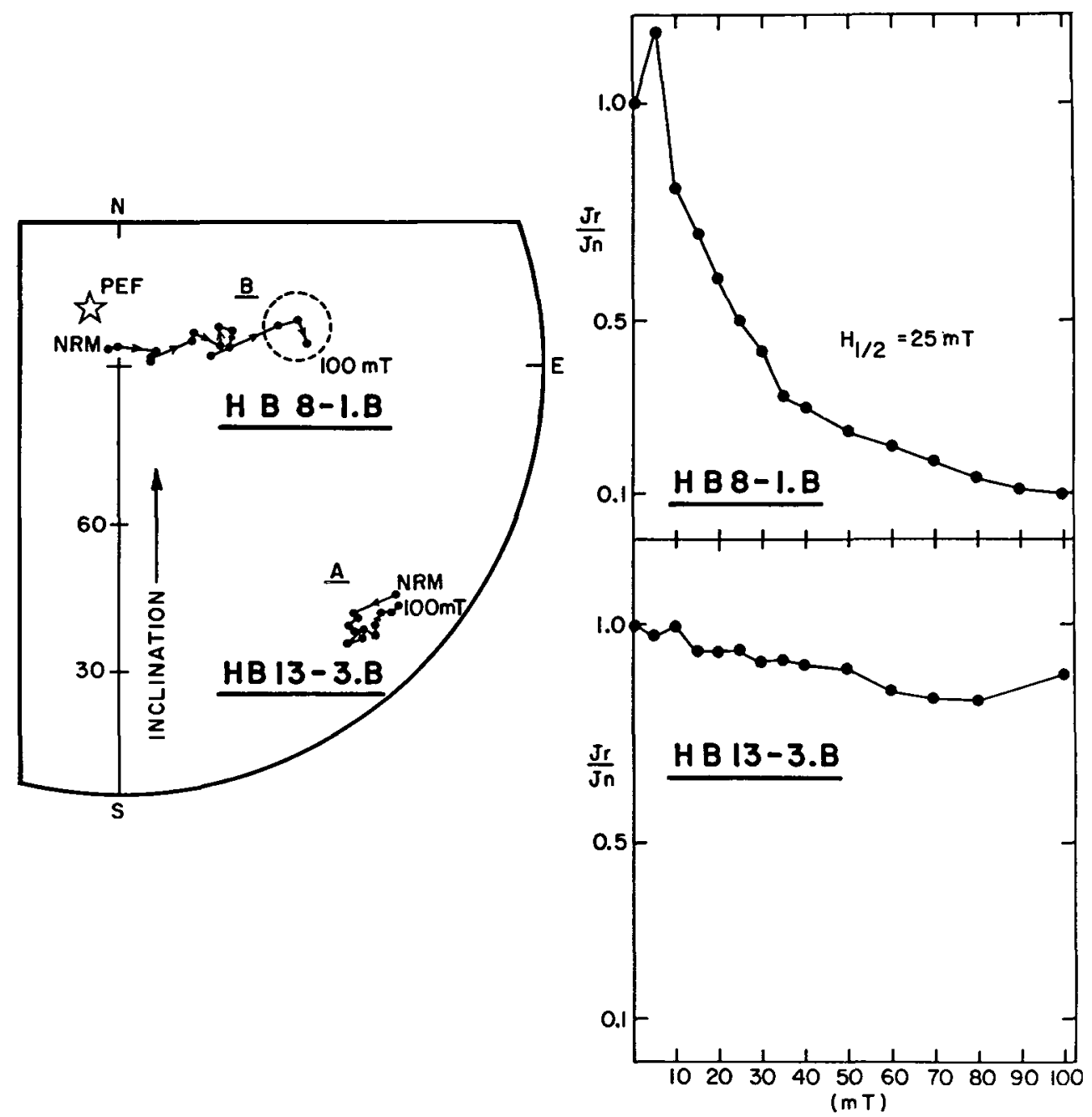

Fig. 4 - Equal-area projections of directions of magnetization (left) of two specimens after stepwise AF demagnetization. Solid (open) circles represent projections on horizontal (vertical) plane. The numbers next to the circles represent the demagnetization steps in $\mathrm{mT}$ as indicated. The respective AF decay curves are shown on the right side. Figure 4 illustrates an example for the isolation of the $A$ and $B$ components.

$T_{\text {UB }}$ is close to the Curie point of magnetite and the second one close to the one of hematite. In slightly over $50 \%$ of the samples, the intensities of magnetization fall off to less than $10 \%$ of the original NRM intensity in the interval: $500-650^{\circ} \mathrm{C}$ (with two modes at 540 and $635^{\circ} \mathrm{C}$ ). Typical kinds of behaviour of a specimen during thermal treatment are shown in Fig. 5. A characteristic univectorial component is obtained as depicted by the linear trajectories on Figure $5 \mathrm{~b}$ from $300^{\circ}$ to $590^{\circ} \mathrm{C}$. In the case of sample $\mathrm{HB} 12-5$, the linear trajectory extends from $450^{\circ}$ to $670^{\circ} \mathrm{C}$ (fig. 5a).

The occasional intensity increase is caused partly by the increase in magnetite content (through oxidation ?) as observed with increasing susceptibility and/or by a low temperature reverse component.

This component $(\mathrm{A})$ is a SE directed magnetization with a shallow downward inclination. In $90 \%$ of the cases, the AF demagnetized and thermally cleaned component on samples from sites $\mathrm{HB} 10,11,12$ and 13 coincided. The situation is more complex on sites HB 8, 9 and 14. For the majority of the specimens from these three sites, $\mathrm{AF}$ and thermally cleaned components in pure magnetite do coincide. This is not so when both hematite and magnetite are present in the same specimen (e.g. HB 8-2C, HB 9-3A, B, C, HB 9-5A, B and the majority of specimens from HB 13). Occasionally both normal and reverse directions are found in the course of thermal demag- 
netization (e.g. $\mathrm{HB}$ 9-3A and $\mathrm{HB}$ 14-1B,C). On sites $\mathrm{HB} 10,11,12$ and 13 , the NRM intensities generally decrease in a uniform manner with increasing temperature. On the three other sites, $60 \%$ of the specimens have shown an increase in the intensity of the residual magnetization in the temperature range: $590-650$ (average: $630^{\circ} \mathrm{C}$ ) suggesting mineralogical change(s) in the original magnetic memory carrier. AF demagnetization was thus believed to be more efficient than thermal cleaning on these three sites. Intermediate coercivities, high $T_{U B}$ and microscopic observations (both transmitted and reflected light) indicated that fine- to medium-grained magnetite is the main memory carrier.

\section{STATISTICAL ANALYSIS OF SITE-MEAN DIRECTION AND ORIGIN OF MAGNETIZATION}

Site-mean directions for combined $\mathrm{AF}$ and thermally cleaned results are shown in Table $l$ along with informations on effective ranges of $\mathrm{AF}$ and thermal treatments and how they were combined in the final data. A present Earth's field (PEF) component is relatively common on sites: HB $8,9,14$ and to a lesser extent on site HB 10. The $\mathrm{SE}+$ component from sites 10 to 14 (A on Table I) is definitely the more stable one. After demagnetization, the declinations are the same as for the initial NRM values; the inclinations did not change substantially but they became more shallow by some $15^{\circ}$. Tests based on stability criteria such as Graham's (1949) fold test cannot be fully performed to infer the age of magnetization of the ignimbrites since at most of the sites the layers have relatively similar strikes and dips. However, a threefold reduction of Fisher's precision parameter for A-sites (Table l) points to a significantly negative fold test.

\section{SAMPLE ALTERATION}

Petrographic and mineralogical studies were then undertaken in order to determine the primary or secondary nature of the opaque minerals which are the magnetic memory carriers. The samples are divided into two sets: 1) $\mathrm{HB} 10,11,12$ and 13 in which there is little or no alteration, and 2) $\mathrm{HB}$ 8, 9 and 14 in which there have been varying amounts of alteration.

\section{1 - Samples HB 10, 11,12 and 13}

Transmitted and reflected light microscopic observations have shown that the main opaque mineral in the red ignimbrites (HB 10, 11, 12 and 13) is specular hematite. A few large corroded crystals of titanomagnetite are also present and the specularite is present within such skeletal crystals. Red fine-grained earthy hematite is usually observed around titanomagnetite crystals, along fractures within such crystals and also in the fine-grained groundmass. Therefore, specularite appears to be an early stage oxidation product of titanomagnetite. Kono and Larson (1980) have

Table 1

FINN HILL SEQUENCE (FHS)

\begin{tabular}{|c|c|c|c|c|c|c|c|c|c|c|c|c|c|c|c|}
\hline $\begin{array}{l}\text { Site } \\
\text { No. }\end{array}$ & $N^{*}$ & $n^{* *}$ & Polarity*** & $\begin{array}{l}\text { Strike } \\
\left({ }^{\circ}\right)\end{array}$ & $\begin{array}{l}\text { Dip } \\
\left(^{\circ}\right)\end{array}$ & Component & $\begin{array}{l}D_{0} 0 \\
\left(^{\circ}\right)\end{array}$ & ${ }_{(0)}^{10}$ & $\underset{\left({ }^{\circ}\right)}{D_{1}}$ & $\begin{array}{l}l_{1} \\
\text { (i) }^{\circ}\end{array}$ & $\alpha_{95}$ & K & $\underset{\mathrm{AF} / \mathrm{T}}{\mathbf{Q}}$ & $\begin{array}{l}T \\
\left({ }^{\circ} \mathrm{C}\right)\end{array}$ & $\underset{(\mathrm{mT})}{\mathrm{AF}}$ \\
\hline 8 & 4 & 12 & $\mathbf{R}$ & 007 & $81 W$ & B & 060 & 58 & 300 & 33 & 10.2 & 82 & $6 / 6$ & $550-625$ & $50-90$ \\
\hline 9 & $\begin{array}{l}3 \\
2\end{array}$ & $\begin{array}{l}7 \\
5\end{array}$ & $\begin{array}{l}R \\
R(?)\end{array}$ & 010 & $82 W$ & B & $\begin{array}{l}075 \\
272\end{array}$ & $\begin{array}{l}45 \\
50\end{array}$ & $\begin{array}{l}306 \\
274\end{array}$ & $\begin{array}{r}47 \\
-32\end{array}$ & 32. & 15 & $4 / 8$ & $500-630$ & $30-90$ \\
\hline 10 & 5 & 12 & $\mathbf{R}$ & 015 & $85 W$ & A & 123 & 31 & 254 & 59 & 10.6 & 53 & $3 / 9$ & $575-645$ & $80-100$ \\
\hline II & 5 & 15 & $\mathbf{R}$ & 012 & $81 W$ & A & 127 & 20 & 219 & 64 & 11.3 & 47 & $2 / 13$ & $575-675$ & $70-90$ \\
\hline 12 & 5 & 13 & $\mathbf{R}$ & 010 & $82 W$ & A & 128 & 23 & 222 & 59 & 9.9 & 61 & $1 / 12$ & $575-670$ & $25-40$ \\
\hline 13 & 5 & II & $\mathrm{R}$ & 004 & $80 \mathrm{~W}$ & A & 134 & 24 & 210 & 50 & 13.3 & 34 & $2 / 9$ & $620-670$ & $50-60$ \\
\hline 14 & $\begin{array}{l}2 \\
2 \\
1\end{array}$ & $\begin{array}{l}4 \\
5 \\
3\end{array}$ & $\begin{array}{l}\mathrm{M} \\
\mathrm{R}\end{array}$ & 008 & $77 w$ & & $\begin{array}{l}185 \\
191 \\
272\end{array}$ & $\begin{array}{r}11 \\
55 \\
-07\end{array}$ & $\begin{array}{l}199 \\
243 \\
261\end{array}$ & $\begin{array}{c}05 \\
09 \\
-69\end{array}$ & - & & $3 / 12$ & $570-650$ & $30-40$ \\
\hline \multirow[t]{2}{*}{ mean: } & \multicolumn{2}{|c|}{4 sites } & $\begin{array}{l}\text { in-situ } \\
\text { tilted }\end{array}$ & & & $\begin{array}{l}\text { A } \\
\text { A }\end{array}$ & 128 & 25 & 225 & 59 & $\begin{array}{r}7.1 \\
13.4\end{array}$ & $\begin{array}{r}171 \\
48\end{array}$ & & & \\
\hline & \multicolumn{2}{|c|}{2 sites } & $\begin{array}{l}\text { in-situ } \\
\text { tilted }\end{array}$ & & & $\begin{array}{l}\text { B } \\
\text { B }\end{array}$ & 069 & 52 & 303 & 40 & - & & & & \\
\hline
\end{tabular}

\footnotetext{
$* N=$ number of samples $\quad * *_{n}=$ number of specimens

***R= reverse $\quad M=$ mixed

$D_{0}, I_{0}=$ demagnetized directions (in-situ)

$D_{1}, I_{1}=$ demagnetized directions (tllt-corrected)

$K=$ estimate of Fisher's precision parameter

$Q=$ ratio of $A F$ demagnetized over thermally cleaned specimens
} 
suggested that specularite is the slightly metamorphosed iron oxide product of titanomaghemites occurring in recent subaerial volcanic rocks.

Transmitted light microscopic studies show that the red ignimbrites are relatively fresh (HB 10, 11, 12, 13); these feldspars (both phenocrysts and microliths) are not much altered. In other places, Nixon (1975) mentions that the feldspars are metamorphic. No primary or even secondary porosity is observed; the fragments are very hard and part of the glassy matrix (perlitic) resembles recent obsidians. These observations indicate that hematite is not a late alteration product because if this was so the whole rock would be uniformly reddish. Thus, if the specularite is not primary, it is definitely primitive, i.e. acquisition of magnetization took place only a short time after the formation and solidification of these ignimbrites. Large blobby droplets of iron oxides in association with the glassy material are definitely primary, while laths and rods of specularite concentrated in the

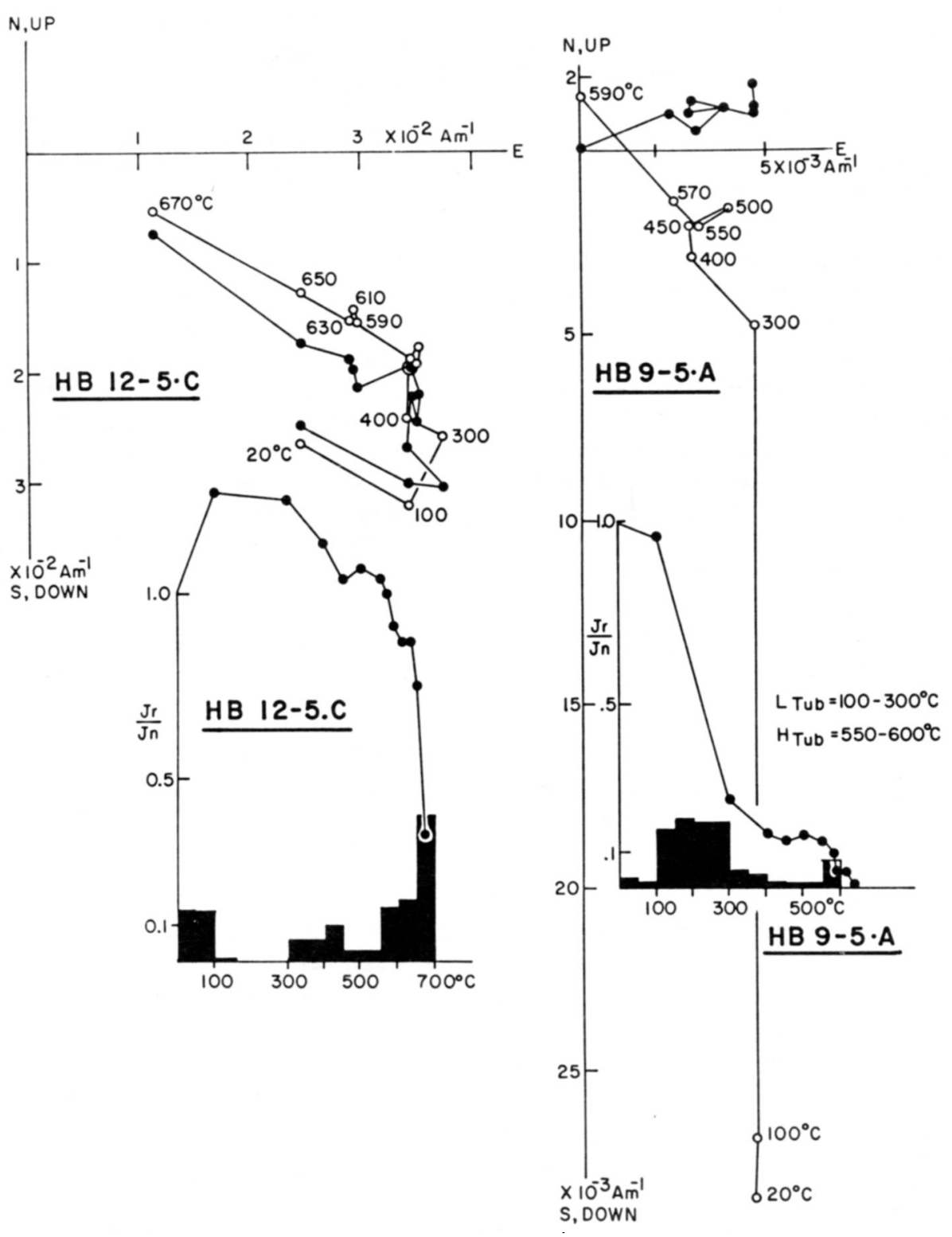

Fig. 5 - Representative orthogonal thermal demagnetization diagrams (Zijderveld 1967) of successive magnetization vectors for two specimens as indicated. The other symbols are as in Figure 4. The numbers next to open circles represent the demagnetization steps $\left({ }^{\circ} \mathrm{C}\right)$. The unblocking temperature $\left(T_{U B}\right)$ in ${ }^{\circ} \mathrm{C}$ is indicated below the orthogonal plots. In Figure 5(b), the two points on the $\mathrm{Jr} / \mathrm{Jn}$ versus $\mathrm{T}$ diagram are not plotted on the Zijderveld diagram because they coincide with the value at $590^{\circ} \mathrm{C}$. 
rest of the matrix (ashes?) are probably primary as well. Modern equivalents are seen in Late Cenozoic volcanism in the Basin and Range province of western United States (Utah, Nevada) (e.g. Crecraft et al. 1981).

\section{Samples HB 8, 9 and 14}

Transmitted and reflected light microscopic observations on specimens from sites HB 8,9 and 14 show very variable phases of oxidation and alteration in contrast to the red ignimbrites. Site HB 14 is the most altered; the feldspars are highly saussuritized and the largest fraction of the rock is chloritized. Specimen HB 14.1 contains a large quantity of small rod-like crystals of specularite. A few relicts and sometimes corroded skeletal crystals of titanomagnetite are rimmed by an aureole of specularite which is in turn surrounded by red earthy hematite. In a few instances, $\mathrm{TiO}_{2}$ has migrated and ferrous iron was transformed to ferric iron in the outer rim of the iron oxide crystals. Specularite and red hematite are the characteristic opaque minerals of the matrix. The cleaned direction of magnetization of the specimens from sample HB 14.1 is quite similar to that of the ones from the $\mathrm{HB} 10,11,12$ and 13 sites but the polarity is reversed. This is not so for the four other samples of $\mathrm{HB} 14$ site in which a mixture of elongated crystals of titanomagnetite and large equant crystals of magnetite are present. Both titanomagnetite and magnetite are fractured, corroded and surrounded by concentric rims of specularite and red earthy hematite. In smaller crystals, hematite appears to be a pseudomorph of magnetite. Some reddish angular fragments contain what appears to be primary or primitive specularite and hematite. Two ages of hematite were observed; one component is older while the other, filling fractures and percolation channels, is definitely secondary. Magnetic memories of varying compositions and ages complicate the analysis and the interpretation of the residual components from this site.

Samples from HB 8 and 9 are less altered than HB 14 but much more so than samples from the other sites. Crystals of magnetite were observed within feldspar phenocrysts and possibly altered pyroxenes. However, most of the oxides were found in the matrix composed of microliths of feldspars and very fine-grained material (glass?). Under high magnification, the opaque minerals within the matrix are more or less equidimensional; both magnetite and titanomagnetite are present. Specularite and fine-grained red hematite are present in the reddish fragments. Rare large magnetite crystals are partly replaced by hematite. It is then difficult to tell whether the magnetite is primary or secondary.

\section{AGE OF ACQUISITION \\ OF MAGNETIZATION}

A synthesis of all the observations mentioned previously (Fig. 6) indicates that the in-situ secondary A component (Table 1) represents a direction of magnetization acquired most probably in late Hadrynian time; the site-mean direction (4 sites) of this component is: $128,+25\left(\alpha_{95}=7^{\circ}, \mathrm{K}=\right.$ 171). Indeed, this component can be correlated with one of the following two orogenic events: 1) Cadomian (Avalonian), and 2) Acadian (Late Devonian) orogenies. Acadian overprinting is shown from radiometric

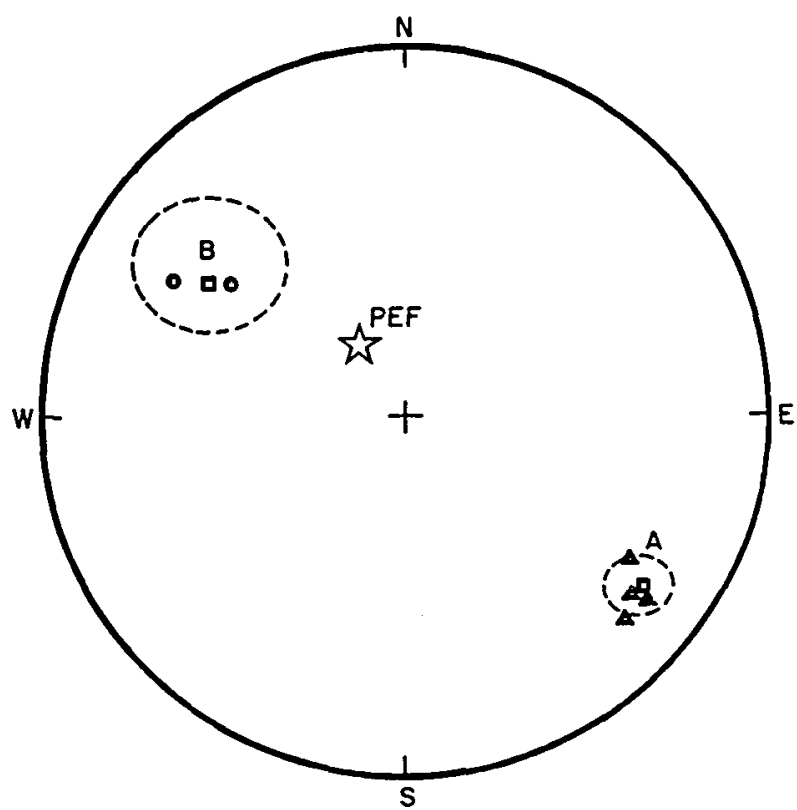

Fig. 6 - Site-mean directions of magnetization plotted on Lambert equal-area net after AF and thermal (combined) cleaning. The in-situ $A$ component and the tilted $\mathrm{B}$ component are identified respectively with solid triangles and circles. The mean value of each component. Is represented by a solid square and the dashed circle shows the cone of $95 \%$ condidence (Fisher 1953). The solid symbols denote downward (positive) inclinations. The star represents the present Earth's field (PEF) at the sampling sites. 
evidence (e.g. Dallmeyer et al. 1983) to be important in the western Avalon Zone of Newfoundland. The effect of Acadian orogeny on the eastern Avalon Zone of Newfoundland is probably milder as the Cambrian-Ordovician sedimentary rocks are practically unmetamorphosed and undeformed. However, unpublished data by E.R. Deutsch and K.V. Rao (personal communication) on the Signal Hill, Black Head Formations and Late Precambrian tilites show a negative fold test possibly due to Acadian overprinting. So overprinting is a possibility in the above mentioned rock units.

I favour a Cadomian rather than Devonian age of acquisition for the $\mathrm{A}$ component mainly because: 1) the Cambro-Ordovician sediments close to the sampling region are undeformed and unmetamorphosed, and 2) the in-situ pole position of the A component $\left(1^{\circ} \mathrm{W}, 14^{\circ} \mathrm{S}\right)$ is very different from Late Devonian poles $\left(115^{\circ} \mathrm{E}, 40^{\circ} \mathrm{N}\right)$ and Permian poles $\left(115^{\circ} \mathrm{E}, 50^{\circ} \mathrm{N}\right)$ from North America. Additional paleomagnetic data from Hadrynian rocks of the Eastern Avalon zone are needed to prove or disprove the above mentioned statement. Component B may either be primary or secondary. Based on the above mentioned observations, this component is more probably primary and correlated with the 700-750 Ma period of formation of the ignimbrite sequence. The tilt corrected site-mean direction of this component is: $303,+40$. The fold axes are subhorizontal and the correction was done by tilting about such axes.

\section{PALEOPOLE POSITIONS AND THEIR RELATIONSHIP OF HADRYNIAN POLES FROM AVALON PENINSULA, THE NORTH AMERICAN CRATON AND NORTHERN EUROPE}

An important gap in the available paleomagnetic data for North America exists in the 950-580 $\mathrm{Ma}$ interval (i.e. from the Helikian-Hadrynian boundary to the Early Cambrian). This remark applies particularly to the Avalon microcontinent. The paleopoles obtained for the Cloud Mountain basalt (Deutsch and Rao 1977) and the Black Head (BH) Formation and Signal Hill (SH) Group (Nairn et al. 1959) are $5^{\circ} \mathrm{S}-8^{\circ} \mathrm{W}$, $5^{\circ} \mathrm{S}-96^{\circ} \mathrm{W}$ and $16^{\circ} \mathrm{S}-38^{\circ} \mathrm{E}$ respectively (Fig. 7). Only the two last rock units belong to the Avalon microcontinent and their pole positions are at least some $60^{\circ}$ apart. The paleopole obtained on the Finn Hill se- quence from the tilt-corrected $\mathrm{B}$ component $(303,+40)$ is $39^{\circ} \mathrm{S}, 29^{\circ} \mathrm{E}$ (antipole; pole = $\left.39^{\circ} \mathrm{N}, 209^{\circ} \mathrm{E}\right)$.

According to King (1979), these rock units in stratigraphic order from bottom to top are: Finn Hill (FH) sequence, SH Group and $\mathrm{BH}$ Formation (which is now recognized as the highest stratigraphic level of the Signal Hill Group); their poles are $39^{\circ} \mathrm{S}-$ $29^{\circ} \mathrm{E}, 16^{\circ} \mathrm{S}-38^{\circ} \mathrm{E}$ and $5^{\circ} \mathrm{S}-96^{\circ} \mathrm{W}$. No specific trend for an APW trajectory is apparent. E.R. Deutsch (personal communication) thinks that the inclusion of the $\mathrm{SH}$ and $\mathrm{BH}$ poles in an APW trajectory is unjustified in view of their uncertain reliability and an uncertainty about their geographic $\mathrm{N}$ or $S$ polarity. Thus, the two present Finn Hill results seem to be the more reliable poles for use in reconstructions for the Hadrynian of Avalon. If the Finn Hill components are correctly interpreted, the APW trajectory moved SSE in Hadrynian time on the Avalon Zone. Additional paleomagnetic studies are needed to construct a reliable Late Precambrian APW trajectory for the Avalon microcontinent and to establish a suitable relationship with the North American craton and western Eurasia.

\section{COMPARISON WITH NORTH AMERICA}

However, some geological constraints can be added to the paleomagnetic results obtained in this study. The late Carboniferous Hercynian Orogeny has only affected parts of the Avalon terrane in Canada, and in Newfoundland its effect is minimal (O'Brien et al. 1983). As the components of magnetization of the Finn Hill sequence cannot be attributed to the Hercynian Orogeny or else with some difficulty to the Acadian Orogeny, it appears worthwhile to compare the late Precambrian paleopoles and paleolatitudes of Newfoundland Avalon with those of similar ages on the western European and Pan-African terranes.

The very late Precambrian paleopoles of cratonic North America (NA), and in particular the. Cloud Mountain basalt pole from western Newfoundland which compares well with other mainland NA late Precambrian poles, are within $10^{\circ}$ to $15^{\circ}$ of pole $\mathrm{A}$ of the Finn Hill sequence (Fig. 7). What is the meaning of this coincidence? Taking for granted that component $A$ is secondary, the most plausible age of acquisition of magnetization is Late Devonian (Acadian orogeny) or late Precambrian (Vendian). The 
Table 2

LATE HADRYNIAN PALEOPOLES OF THE NORTH AMERICAN CRATON AND AVALON Pole Position

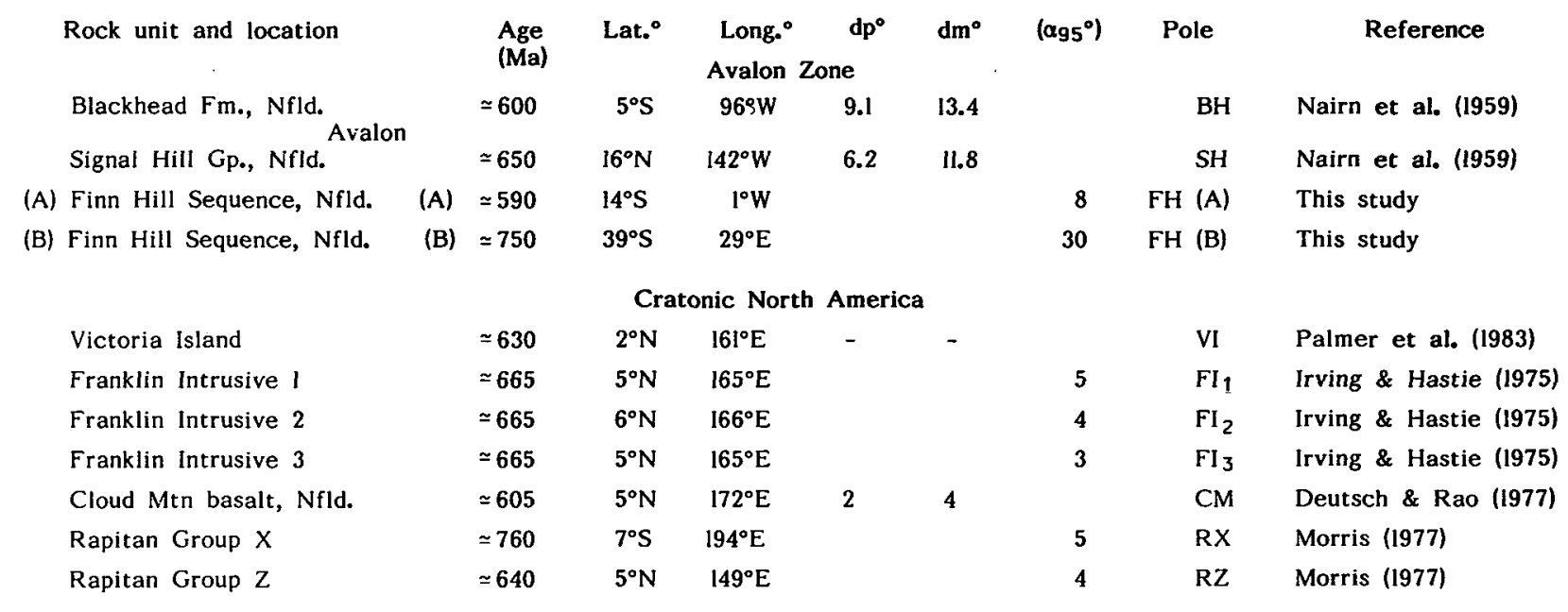

pole position of component $A$ is very remote from any known NA Devonian paleopole and thus a late Precambrian age of magnetization is more appropriate for component $A$. This leads to the conclusion that at that time NA and Avalon were probably not very remote from each other; they could be at least $500 \mathrm{~km}$ away given the amount of inherent error in the method.

\section{Comparison with Europe and \\ Pan-African belts}

Paleomagnetic studies in the Precambrian of the Avalonian, Pan-African and northwestern European terranes are critical in understanding Late Precambrian tectonics of these areas. Unfortunately, such paleomagnetic studies are very limited in number and contain relatively large circles of confidence; this does not allow easy geodynamic conclusions. In attempting to draw comparisons between the Avalonian and other Atlantic-bordering terranes, the Armorican data especially should be used with caution since the case for APW relative to Armorica is still ill-defined probably because of effect of a major Hercynian overprint, the internal consistency of the data (e.g. Perigo et al. 1983) is poor; still, using their own assessment of age control of magnetization and of the magnetic reliability, a mean direction for Ca. $610 \mathrm{Ma}$ can be obtained by respective interpolation from a) one of two clusters with poles $\mathrm{KMB}, \mathrm{SP}$ and $\mathrm{SQ}$, all paleomag- netically reliable and reasonably well dated, but with an age spread of about $60 \mathrm{Ma}$ between the first two and the last pole (mean pole: $37^{\circ} \mathrm{N}, 120^{\circ} \mathrm{E}$ ) and b) a second cluster consisting of 7 poles (GKI, SQ2, KHI, JD, PPI, PP2 and PP3), of which two have low paleomagnetic reliability, the second to fourth have no age control and the other four (GKl, PPI-3) have a substantial age uncertainty $(85$. Ma) with a mean pole of ca. $30^{\circ} \mathrm{N}, 230^{\circ} \mathrm{E}$. The two clusters are more than $100^{\circ}$ apart. Hagstrum et al. (1981) pointed out that the Eocambrian Armorican APW path is quite similar to that of Africa and reconstructed Gondwana. In NW Africa, the paleopole is close to $40^{\circ} \mathrm{N}, 230^{\circ} \mathrm{E}$ with a paleolatitude of $8^{\circ} \mathrm{N}$ (Kent et al. 1984); it is comparable to the mean pole $\left(30^{\circ} \mathrm{N}\right.$, $230^{\circ} \mathrm{E}$ ) of the second cluster (paleolatitude: $\left.15^{\circ} \mathrm{N}\right)$. The anti-paleopole and paleolatitude of the in-situ $A$ component is $179^{\circ} \mathrm{E}, 14^{\circ} \mathrm{N}$ and $13^{\circ} \mathrm{N}$. Using this data base for comparison, it is noted that the paleolatitudes of the Armorican, Pan-African and Avalonian terranes could be similar $\left(8^{\circ}\right.$ to $\left.15^{\circ} \mathrm{N}\right)$ and situated close to the paleoequator. As this comparison is supported by incomplete data sets from both Armorica and Avalon, Late Hadrynian paleomagnetic data base ought to be enlarged with additional local and regional studies from both sides of the Atlantic to test accurately the above mentioned possibility. The following section is more speculative.

After allowing for the restoration of the present Atlantic Ocean, the Eocambrian A 


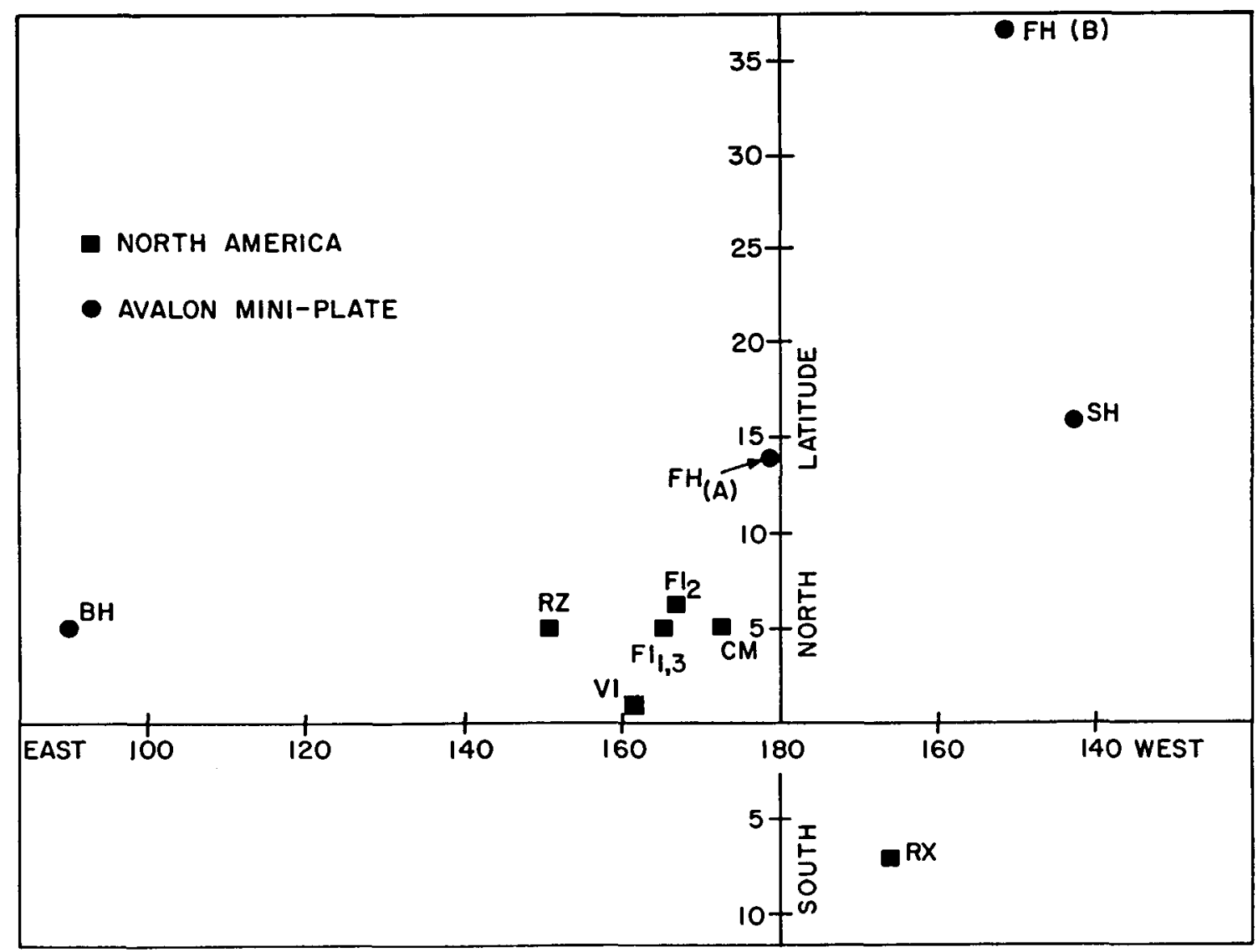

Fig. 7 - Paleomagnetic poles (late Hadrynian) derived from Avalon zone and cratonic North America (Table 2).

pole of Avalon is situated at approximately $214^{\circ} \mathrm{E}$ and $20^{\circ} \mathrm{N}$; this relocated paleopole position is not significantly different from that of Eocambrian Armorican and PanAfrican terranes. The present latitudinal difference between North Africa (e.g. Morocco) and Armorica is $10-15^{\circ}$ and it was not much greater in Eocambrian time; the same conclusion applies to Newfoundland. In the Eocambrian-Cambrian interval, Armorica, Pan-Africa and Avalonia probably moved as a single unit. Their convergence by Late Precambrian time may be related to the Cadomian orogeny. Earlier than 620 $\mathrm{Ma}$ (i.e. at $750 \mathrm{Ma})$, the $\mathrm{B}$ paleopole $\left(209^{\circ} \mathrm{E}\right.$ $\left.39^{\circ} \mathrm{N}\right)$ and paleolatitude $\left(22^{\circ} \mathrm{N}\right)$ of the Avalonian terrane are not similar, after closure of the present Atlantic Ocean, to those of the Armorican and Pan-African terranes. The reason for their difference may be related to the small quantity and/or poor quality of the existing paleomagnetic data, the unreliable age control of the magnetizations or other causes. In northwest Europe (northern Great Britain, Scandinavia) the paleopole for this period could be close to $300^{\circ} \mathrm{E}, 50^{\circ} \mathrm{S}$ while for Africa, the paleopole position is close to $300^{\circ} \mathrm{E}, 60^{\circ} \mathrm{S}$ (Brock 1981). Consequently, it seems that Pan-Africa, Armorica and Avalonia were dispersed before $620 \mathrm{Ma}$ but located close to each other and the paleo-equator in late Hadrynian time.

\section{ACKNOWLEDGEMENTS}

The author thanks Dr. E.R. Deutsch and Mr. T. Vallis (Department of Earth Sciences, Memorial University of Newfoundland) for assistance in drilling and cutting of oriented rock samples, Mr. R.V. Rao (Université Laval) for field assistance and Mr. R. Ouellet (Engineering Physics Program, Université Laval) who made a large part of the measurements. This work was supported by EMR research agreement (Canada) No. 128-3-80.

\footnotetext{
ANDERSON, M.M. 1972. A possible time span for the late Precambrian of the Avalon Peninsula, Southeastern Newfoundland in the light of world-wide correlation of fossils, tillites, and rock units within the succession. Canadian Journal of Earth Sciences, 9, pp. 1710-1726.
} 
BROCK, A. 1981. Paleomagnetism of Africa and Madagascar. In Paleoreconstruction of the Continents: McElhinny, M.W. and Valencio, D.A. Editors. Geodynamics Series, 2, AGU, pp. 65-76.

CHOUBERT, B. 1935. Recherches sur la genèse des chaînes paléozoiques et anté-cambriennes. Revue Géographie Physique et de Géologie Dynamique, 8, pp. 5-50.

COGNE, J. 1972. Le Briovérien et le cycle orogenique cadomien dans le cadre des orogènes fini-précambriennes. Notes Mém. Serv. Géol. Maroc, 236, pp. 193-213.

CRECRAFT, H.R., NASH, W.P. and EVANS, S.H. Jr. 1981. Late Cenozoic Volcanism at Twin Peaks, Utah: Geology and Petrology. Journal of Geophysical Research, 86, No. Bll, pp. 10303-10320.

DALLMEYER, R.D., HUSSEY, E.M., O'BRIEN, S.J. and O'DRISCOLL, C.F. 1983. Chronology of tectonothermal activity in the western Avalon Zone of the Newfoundland Appalachians. Canadian Journal of Earth Sciences, 20, pp. 355-363.

DEUTSCH, E.R. and RAO, K.V. 1977. New palaeomagnetic evidence fails to support rotation of western Newfoundland. Nature, 266, pp. 314-318.

FISHER, R.A. 1953. Dispersion on a sphere. Proceedings Royal Society London, A217, pp. 295-305

GRAHAM, J.W. 1949. The stability and significance of magnetism in sedimentary rocks. Journal of Geophysical Research, 59, pp. 131-167.

HAGSTRUM, J.T., VAN DER VOO, R., AUVRAY, $B$, et BONHOMMET, N. 1980. Eocambrian-Cambrian palaeomagnetism of the Armorican Massif, France. Geophysical Journal of the Royal astonomical Society, 61, pp. 489-5I7.

HUGHES, C.J. and BRUCKNER, W.D. 1972. Late Precambrian rocks of Eastern Avalon Peninsula Newfoundland - a volcanic island complex: Reply. Canadian Journal of Earth Sciences, 9, pp. 1059-1060.

HUTCHINSON, R.D. 1953. Geology of Harbour Grace map-area. Newfoundland, Geological Survey of Canada, Memoir 275, 43p.

IRVING, E. and HASTIE, J. 1975. Catalogue of paleomagnetic directions and poles. Second issue. Precambrian results 1957-1974. Geomagnetic Series No. 3, Earth Physics Branch, Ottawa, 42p.

KENT, D.V., DIA, O., and SOUGY, J.M.A. 1984. Paleomagnetism of lower-middle Devonian and upper Proterozoic-Cambrian (?) rocks from Mejeria (Mauritania, West Africa). In Plate Reconstruction from Paleozoic Paleomagnetism: R. Van der Voo, C.R. Scotese and N. Bonhommet editors. Geodynamics Series 12, AGU, pp. 99-115.

KING, A.F. 1979. The Birth of the Caledonides: Late Precambrian Rocks of the Avalon Peninsula, Newfoundland, and their Correlations in the Appalachian-Orogen. In the Caledonides in the U.S.A. International Correlation Program (IGCP) Project 27.

KING, A.F., BRUCKNER, W.D., ANDERSON, M.M. and FLETCHER, T.P. 1974. Late Precambrian and Cambrian sedimentary sequences of eastern Newfoundland. Geological Association of Canada, Annual Meeting, Field Trip Manual B-6, 59p.

KONO, M. and LARSON, E.E. 1980. Fe-Ti oxide mineralogy of DSDP leg 55 basalts. In Initial Reports of the Deep Sea Drilling Project, LV, Washington, D.C., pp. 639-652.
KROGH, T.E., STRONG, D.F. and PAPEZIK, S.V. 1983. Precise $\mathrm{U}-\mathrm{Pb}$ ages of zircons from volcanic and plutonic units in the Avalon Peninsula. 18th annual meeting of the NE section of the Geological Society of America, Abstract, p. 135.

LILLY, H.D. 1966. Late Precambrian and Appalachian tectonics in light of submarine exploration on the Grand Bank of Newfoundland and in the Gulf of St. Lawrence: Preliminary Views. American Journal of Science 264, pp. 569-574.

MCCARTNEY, W.D. 1956. Argentia, Newfoundland. Geological Survey of Canada, Preliminary map, Paper 55-11.

MCCARTNEY, W.D. 1967. Whitbourne map-area, Newfoundland. Geological Survey of Canada, Memoir 341, 135p.

MORRIS, W.A. 1977. Paleolatitude of glaciogenic upper Precambrian Rapitan Group and the use of tillites as chronostratigraphic marker horizons. Geology 5, pp. 85-88.

NAIRN, A.E.M., FROST, D.V. and LIGHT, B.G. 1959. Paleomagnetism of certain rocks from Newfoundland, Nature, 183, pp. 596-597.

NIXON, G.T. 1975. Late Precambrian (Hadrynian) ash-flow tuffs and associated rocks of the Harbour Main Group near Colliers, Avalon Peninsula, southeast Newfoundland. M.Sc. thesis, Memorial University of Newfoundland, St. John's, Nfld.

NIXON, G.T. and PAPEZIK, V.S. 1979. Late Precambrian ash-flow tuffs and associated rocks of the Harbour Main Group near Colliers, eastern Newfoundland; Chemistry and magnetic affinities. Canadian Journal of Earth Sciences, 16, pp. 167181.

O'BRIEN, S.J., WARDLE, R.J. and KING, A.F. 1983 The Avalon Zone: A Pan-African terrance in the Appalachian Orogen of Canada. Geological Journal, 18, pp. 195-222.

PALMER, H.C., BARAGAR, W.R.A., FORTIER, M. and FOSTER, J.H. 1983. Paleomagnetism of Late Protorozoic rocks, Victoria Island, Northwest Territories, Canada. Canadian Journal of Earth Sciences, 20, pp. 1456-1469.

PAPEZIK, V.S. 1969. Late Precambrian ignimbrites in the Avalon Peninsula, Newfoundland. Canadian Journal of Earth Sciences, 6, pp. 1405-1414.

PAPEZIK, V.S. 1970. Petrochemistry of volcanic rocks of the Harbour Main Group, Avalon Peninsula, Newfoundland. Canadian Journal of Earth Sciences, 7, pp. 1485-1498.

PAPEZIK, V.S. 1972. Late Precambrian ignimbrites in eastern Newfoundland and their tectonic significance. 24th International Geological Congress Proceedings, Section 1, pp. 147-152.

PERIGO, R., VAN DER VOO, R., AUVRAY, B. and BONHOMMET, N. 1983. Palaeomagnetism of Late Precambrian-Cambrian volcanics and intrusives from the Armorican Massif, France. Geophysical Journal of the Royal astronomical Society, 75, pp. 235-260.

POOLE, W.H. 1967. Tectonic evolution of Appalachain region of Canada. In Geology of the Atlantic region. Edited by E.R.W. Neale and H. Williams. Geological Association of Canade, Special Paper 4, pp. 9-5l.

RANKIN, D.W. 1976. Appalachian salients and recesses: Late Precambrian Continental break-up and the opening of the Iapetus Ocean. Journal 
of Geophysical Research, 81, pp. 5605-5619.

RAST, N., O'BRIEN, B.H. and WARDLE, R.J. 1976. Relationship between Precambrian and Lower Paleozoic rocks of the "Avalon Platform" in New Brunswick, the northeast Appalachians and the British Isles. Tectonophysics, 30, pp. 315-338.

SCHENK, P.E. 1971. Southeastern Atlantic Canada, northwestern Africa and continental drift. Canadian Journal of Earth Sciences, 8, pp. 1218-1251.

SEGUIN, M.K. 1975. Conception et réalisation d'un appareil de désaimantation par champs alternatifs et son utilisation dans les études paléomagnetiques. Abhandlungen der Braunschweigischen Wissenschaftlichen Gesellschaft, Band XXV, pp. 25-43.

STRONG, D.F. 1979. Proterozoic tectonics of northwestern Gondwanaland. New evidence from eastern Newfoundland. Tectonophysics, 54, pp. 81-101.

STRONG, D.F., DICKSON, W.L., O'DRISCOLL, C.F., KEAN, B.F. and STEVENS, R.K. 1974. Geochem-

i cal evidence from eastward Appalachian subduction in Newfoundland. Nature, 248, pp. 37-39.

STUKAS, V.J. 1977. Plagioclase Release Patterns: A High Resolution ${ }^{40} \mathrm{Ar} /{ }^{39} \mathrm{Ar}$ Study. Thesis, Dalhousie University.

STUKAS, V.J. and REYNOLDS, P.R. 1976. ${ }^{40} \mathrm{Ar} /{ }^{39} \mathrm{Ar}$ dating of terrestrial materials: a review of recent studies with particular emphasis on plagioclase release patterns. Program with Abstracts, 1, GAC-MAC Annual Meeting, Edmonton (Alta).

WILLIAMS, H. 1979. Appalachian Orogen in Canada. Canadian Journal of Earth Sciences, 16, pp. 792807.

WILLIAMS, H., KENNEDY, M.J. and NEALE, E.R. 1972. The Appalachian structural province, in Price, R.A. and Douglas, R.J.W. (Eds.). Variations in tectonic styles in Canada: Geological Association of Canada Special Paper 11, pp. 181-261.

WILLIAMS, H. and HATCHER, R.D. Jr. 1982. Suspect terranes and accretionary history of the Appalachian orogen. Geology, 10, pp. 530-536.

WILLIAMS, H. and HATCHER, R.D. Jr. 1983. Appalachian Suspect Terranes. Geological Society of America, Memoir 158, pp. 33-53.

WILLIAMS, H. and KING, A.F. 1979. Trepassey map area, Newfoundland. Memoir Geological Survey of Canada, 389.

ZIJDERVELD, J.D.A. 1967. A.C. demagnetization of rocks: analysis of results. In Methods in paleomagnetism. Edited by D.W. Collinson, K.M. Creer and S.V. Runcorn. Elsevier, Amsterdam, The Netherlands, pp. 254-286.

REVIEWERS: H.G. Miller

S. Colman-Sadd

Anonymous (from D. Colman-Sadd) 